\title{
Impact of draining hilly lands on runoff and on-site erosion: a case study from humid Ethiopia
}

\author{
Elise Monsieurs, ${ }^{1,2 *}$ Mekete Dessie, ${ }^{3,4}$ Niko E. C. Verhoest, ${ }^{4}$ Jean Poesen, ${ }^{5}$ Enyew Adgo, ${ }^{6}$ Jozef Deckers ${ }^{5}$ and Jan Nyssen ${ }^{2}$ \\ 1 Department of Earth Sciences, Royal Museum for Central Africa, Tervuren, Belgium \\ ${ }^{2}$ Department of Geography, Ghent University, Ghent, Belgium \\ 3 School of Civil and Water Resources Engineering, Bahir Dar University, Bahir Dar, Ethiopia \\ ${ }^{4}$ Laboratory of Hydrology and Water Management, Ghent University, Ghent, Belgium \\ ${ }^{5}$ Department of Earth and Environmental Sciences, KU Leuven, Leuven, Belgium \\ ${ }^{6}$ Department of Natural Resource Management, Bahir Dar University, Bahir Dar, Ethiopia
}

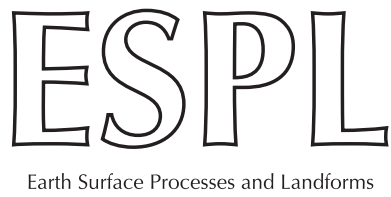

\begin{abstract}
The use of drainage ditches on farmland has an impact on erosion processes both on-site and off-site, though their environmental impacts are not unequivocal. Here we study the runoff response and related rill erosion after installing drainage ditches and assess the effects of stone bunds in north Ethiopia. Three different land management systems were studied in 10 cropland catchments around Wanzaye during the rainy season of 2013: (1) the exclusive use of drainage ditches (locally called feses), (2) the exclusive use of stone bunds, and (3) a mixture of both systems. Stone bunds are an effective soil and water conservation technique, making the land more resistant against on-site erosion, and allowing feses to be installed at a larger angle with the contour. The mean rill volumes for the 10 studied cropland catchments during the rainy season of 2013 was $3.73 \pm 4.20 \mathrm{~m}^{3} \mathrm{ha}^{-1}$ corresponding to a soil loss of $5.72 \pm 6.30$ ton $\mathrm{ha}^{-1}$. The establishment of feses causes larger rill volumes $(R=0.59, N=10)$, although feses are perceived as the best way to avoid soil erosion when no stone bunds are present. The use of feses increases event-based runoff coefficients (RCs) on cropland from c. $5 \%$ to values up to $39 \%$. Also, a combination of low stone bund density and high feses density results in a higher RC, whereas catchments with a high stone bund density and low feses density have a lower RC. Peak runoff discharges decrease when stone bund density increases, whereas feses density is positively related to the peak runoff discharge. A multiple linear relation in which both feses and stone bund densities are used as explanatory variable, performs best in explaining runoff hydrograph peakedness $\left(R^{2}=83 \%\right)$. Copyright $@ 2015$ John Wiley \& Sons, Ltd.
\end{abstract}

KEYWORDS: drainage; stone bunds; soil conservation; peak runoff; degradation

\section{Introduction}

In traditional rural areas where soils have poor internal drainage and where the rainfall depth exceeds the evapotranspiration depth, drainage ditches are commonly established manually (Shiferaw, 2002; Turkelboom et al., 2008; Monsieurs et al., 2015b). Hydrogeomorphic impacts of drainage ditches have been reviewed by Monsieurs et al. (2015a), yet they state that it is hard to conclude on the final balance between the positive and negative effects following the use of drainage ditches. Overall, surface drainage ditches have a positive impact on aeration of the soil, crop growth and soil structure (e.g. Luthin, 1966; Robinson, 1990; Spaling and Smit, 1995; Zhang et al., 2013). Yet, negative impacts concern off-site impacts such as higher peak runoff discharges, gully initiation, flooding, and an increase in sediment load, whereas on-site problems are less documented (Monsieurs et al., 2015a).

Cropland management affects soil loss. The widespread traditional drainage ditches in the humid parts of Ethiopia are perceived as indigenous soil and water conservation (SWC) practices (e.g. Million, 1996; Herweg and Ludi, 1999; Zegeye et al., 2010). Also Gessesse (2014) emphasizes that drainage ditches in the Lake Tana basin provide protection against erosion when properly constructed, i.e. with no excessive ditch gradients and appropriate depth. When the collected runoff is drained to common areas and the erosion features are not always clearly visible, farmers do not perceive traditional ditches as inducing erosion problems (Gessesse, 2014). On the one hand, Million (1996) states that drainage ditches in the Ethiopian highlands are not a useful SWC tool, but a simple drainage technique causing severe erosion hazards on steep slopes although croplands without drainage ditches were seriously affected by rill erosion. On the other hand, soil loss on cropland is reduced after stone bund implementation, but most of the studies related to this technique were conducted in semiarid and subhumid areas (e.g. Gebremichael et al., 2005; Vancampenhout et al., 2006; Nyssen et al. 2007). Yet no quantitative studies and only scarce qualitative studies have been conducted to compare rates of soil loss from cropland where drainage ditches or stone bunds are implemented (e.g. Reij, 1996; Amsalu, 2006; Amsalu and de Graaff, 2007). Herweg and Ludi (1999) measured soil loss and runoff for different 
SWC techniques applied in different climatic areas in Ethiopia including stone bunds and other versions of traditional drainage ditches, i.e. Fanya Juu and double ditches, both consisting of a small dam and a ditch. No significant soil loss differences between the SWC treatments were found and the effects on runoff and crop production were not clear. Graded structures were found to increase runoff, causing erosion of the drainage ditches and loss of precious moisture for crop production (Herweg and Ludi, 1999).

Hydrograph characteristics of runoff events are related to the type of erosion processes for which it is interesting to seek for a relation with land management practices. However, research on this topic is limited. Peak flow discharge and runoff volume drive the erosion process (Woodward, 1999). Channel erosion, and thus sediment transport will be larger when the runoff peak discharge increases (Simon and Rinaldi, 2006). In this study we focus on the hydrograph peakedness as artificial drainage is found to cause a higher peak runoff (Skaggs, 1994; Holden, 2004) and hence, higher erosion rates (Hooke, 1979). Different measures are used by different authors for expressing runoff peakedness of which we will discuss the following: (1) kurtosis (Fryirs and Brierley, 2012); (2) velocity of rise time (VRT, in s ${ }^{-1}$ ), i.e. an index we developed for the increase of runoff discharge during a fixed period before the peak was reached, and (3) peak flow discharge over base time (QBT, in $\mathrm{m}^{3} \mathrm{~s}^{-1}$ ) (Gordon et al., 2004). Conway and Millar (1960) found artificially drained areas to have an increased sensitivity of runoff response to rainfall causing higher peak flows. Armstrong and Garwood (1991) found lowered groundwater tables and reduced waterlogging in artificially drained plots, although their effects on peak flows were found to be small. Carluer and De Marsily (2004) state that in rural catchments, drainage ditches may accelerate the flow from the field to the river. But conversely, if the ditches are dry they may help the water to infiltrate (Marofi, 1999). Stone bunds reduce the quantity and eroding capacity of overland flow (Bosshart, 1997; Taye et al., 2013). This was confirmed by Nyssen et al. (2007) who state that stone bunds bring positive off-site effect such as runoff reduction and flood regulation.

Rill erosion and gully formation are the most important processes causing soil loss by water which, together with the loss of rainwater (Poesen et al., 2003), form a severe threat to the subsistence rainfed agriculture and the national economy of Ethiopia (Bewket and Sterk, 2003; Tebebu et al., 2010). Thus lack of knowledge on (1) the process of gully erosion (off-site processes) and (2) the environmental impacts (on-site processes) of artificial drainage (Skaggs et al., 1994) is problematic as it may lead to mismanagement in the basin. The off-site impacts of drainage ditches on cropland have been recently reported by Monsieurs et al. (2015b). The objectives of this paper are to understand the impact of both drainage ditches and stone bunds on the on-site runoff response and rill erosion.

\section{Study Area}

\section{Lake Tana basin}

Lake Tana is the largest lake in Ethiopia and its catchment covers some $16500 \mathrm{~km}^{2}$, including the lake area. The lake is situated in the north-western part of Ethiopia (between $11^{\circ} 00^{\prime}$ $\mathrm{N}$ and $12^{\circ} 50^{\prime} \mathrm{N}, 36^{\circ} 30^{\prime} \mathrm{E}$ and $38^{\circ} 20^{\prime} \mathrm{E}$ ), forming a depression in the Ethiopian highlands at $1786 \mathrm{~m}$ above sea level (a.s.l.) (Setegn et al., 2010). The climate in Lake Tana basin is 'cool to cold tropical highland monsoon' (Dargahi and Setegn, 2011). Rainfall is locally variable in the region, with a basinwide annual average of $1421 \mathrm{~mm}$ (Conway, 2000) and 70\% of the total rainfall occurring in the Kiremt season (June-September). The soils of the Lake Tana basin are derived from weathered volcanic rocks (Poppe et al., 2013). The majority of the basin has deep to very deep soils whereas soils on hill slopes are shallow or very stony (Easton et al., 2010; Engda, 2010; Kebede et al., 2011). The fertile soils on the lacustrine deposits and the weathering materials of the basalts make the Lake Tana basin an important region for Ethiopia (Colot, 2012).

In the Lake Tana basin, stone bunds have been found to reduce surface runoff and soil loss (Schürz et al., 2013; Brenner et al., 2013). Other research confirms the positive off-site and on-site effects of stone bunds (Haregeweyn, 2015). But over a longer time span, possible negative consequences such as concentration of runoff, ponding of water, piping under structures or the creation of fertility gradients have to be taken into account (Nyssen et al., 2007; Alt et al., 2009). On-site conservation methods on farmland are still in an experimental stage and not widely practiced.

\section{Land surface management in Kizin and Wonzima catchments}

Fieldwork was conducted in the Kizin and Wonzima catchments near the village of Wanzaye during the rainy season (July-September) of 2013 (Figure 1). Both catchments are moderately to dominantly cultivated. They are part of the Gumara sub-basin $\left(1236 \mathrm{~km}^{2}\right)$. Soils in the Gumara sub-basin are Eutric Vertisols, Eutric Fluvisols, Chromic Luvisols, Eutric Leptosols, and a dominance of Haplic Luvisols (Colot, 2012; Poppe et al., 2013).

Land management practices in the study area are strongly related to the highly seasonal rainfall pattern. Three practices are applied around Wanzaye as well as in the wider region: (1) stone bunds, (2) drainage ditches (locally called feses), and (3) the combined use of both techniques (Monsieurs et al., $2015 \mathrm{a}, 2015 \mathrm{~b})$. The combined use of stone bunds and feses is not exclusive for the area around Wanzaye. Reij et al. (1996) state that for regions with annual rainfall approaching $1000 \mathrm{~mm}$ or more, combinations of SWC practices (for example stone bunds) and drainage ditches in farm fields with a risk of waterlogging, are common (e.g. in the Mandara mountains, north Cameroon).

We opted to work at a catchment scale rather than at a plotscale as plot-scale studies show limitations of which the decisive one was the restriction to extrapolate results from runoff plots to catchments (Nyssen et al., 2004, 2010a; Awulachew et al., 2008). Ten cropland catchments (CAs) have been selected based on feses density and presence or absence of stone bunds, and delineated by a handheld global positioning system (GPS) (Garmin eTrex). Catchment areas range from 0.27 ha (CA 10 ) to 4.21 ha (CA 3), with a mean catchment area of 1.65 \pm 1.25 ha. The average slope gradient of the 10 catchments ranges between 0.06 and $0.23 \mathrm{~m} \mathrm{~m}^{-1}$ (Table I). General analyses of stone bund density, feses density, surface rock fragment cover, soil depth, catchment slope gradient, angle between established feses and the contour; feses gradient and total rill volume per area are based on measurements from these 10 catchments. Stone bund and feses densities vary among the 10 study catchments (Table I), with a mean feses density of $254 \pm 179 \mathrm{~m} \mathrm{ha}^{-1}$, and mean stone bund density (SBD) of 277 $\pm 340 \mathrm{~m} \mathrm{ha}^{-1}$. One catchment without drainage ditches (CA 2) and one without stone bunds (CA 6) were selected as well. Although we are aware of the potential effects of footpaths on runoff (Harden, 1992; Ziegler et al., 2000; Turkelboom et al., 2008), footpaths are not included for the calculation of feses 


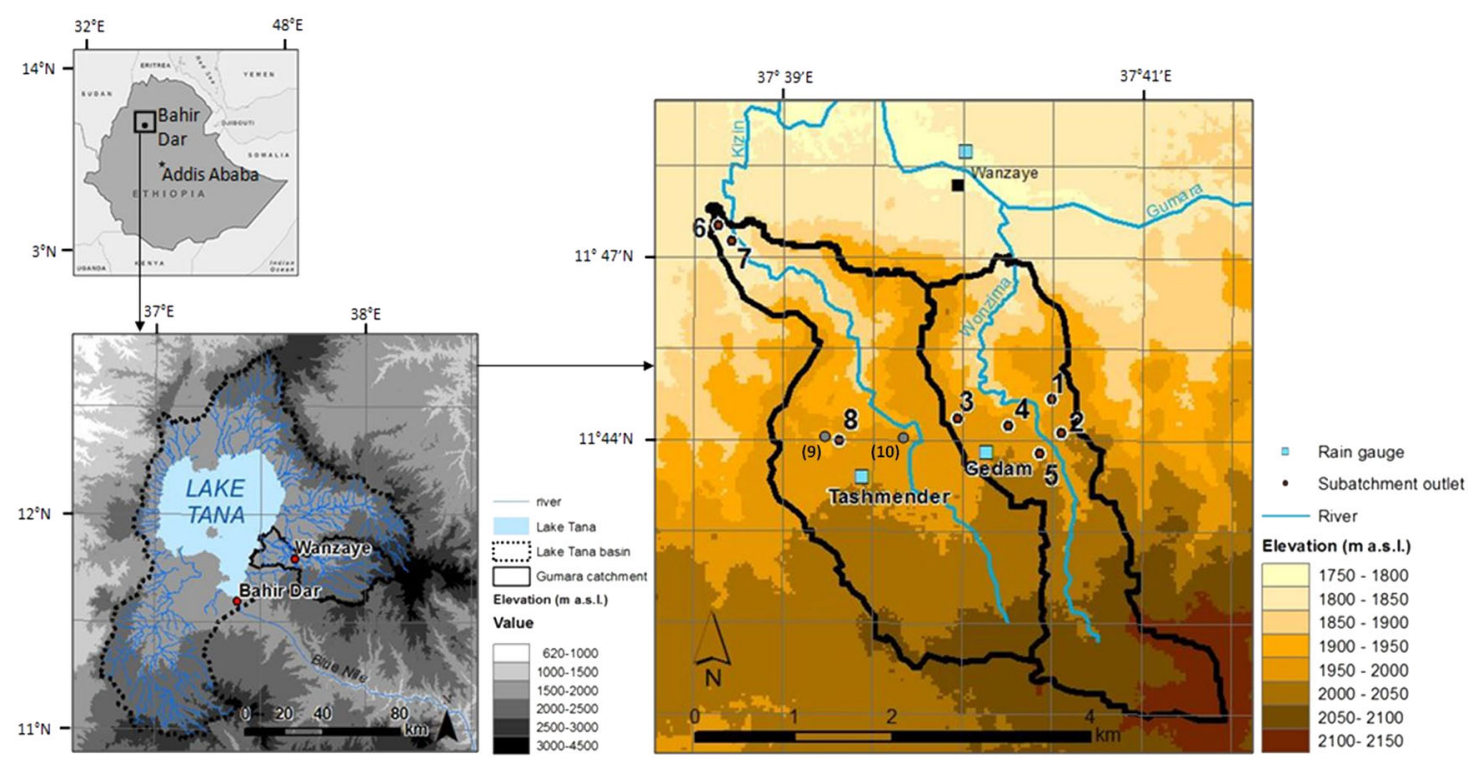

Figure 1. Location of the study area in Ethiopia and the 10 selected subcatchments and rain gauges in the Lake Tana basin. The map on the right shows the subcatchments Kizin (on the left) and Wonzima (on the right). Two outlier catchments (9 and 10) are marked by a grey dot. This figure is available in colour online at wileyonlinelibrary.com/journal/espl

Table I. Characteristics of the 10 studied cropland catchments (CA)

\begin{tabular}{lccrrrr}
\hline CA & $\begin{array}{c}\text { Area } \\
\text { (ha) }\end{array}$ & $\begin{array}{c}\text { ASG } \\
\left(\mathrm{m} \mathrm{m}^{-1}\right)\end{array}$ & $\begin{array}{r}\text { TFL } \\
(\mathrm{m})\end{array}$ & $\begin{array}{r}\text { FD } \\
\left(\mathrm{m} \mathrm{ha}^{-1}\right)\end{array}$ & $\begin{array}{r}\text { TSL } \\
(\mathrm{m})\end{array}$ & $\begin{array}{c}\text { SBD } \\
\left(\mathrm{m} \mathrm{ha}^{-1}\right)\end{array}$ \\
\hline 1 & 1.94 & 0.20 & 404 & 209 & 1021 & 528 \\
2 & 1.76 & 0.06 & 0 & 0 & 789 & 448 \\
3 & 4.21 & 0.08 & 1038 & 247 & 306 & 73 \\
4 & 3.51 & 0.09 & 187 & 53 & 1364 & 388 \\
5 & 1.63 & 0.06 & 683 & 418 & 454 & 278 \\
6 & 1.44 & 0.06 & 584 & 406 & 0 & 0 \\
7 & 0.73 & 0.07 & 57 & 78 & 276 & 379 \\
8 & 0.56 & 0.06 & 106 & 188 & 353 & 626 \\
9 & 0.41 & 0.11 & 177 & 431 & 20 & 50 \\
10 & 0.27 & 0.23 & 135 & 510 & 0 & 0 \\
Minimum & 0.27 & 0.06 & 0 & 0 & 0 & 0 \\
Maximum & 4.21 & 0.23 & 1038 & 510 & 1364 & 626 \\
Mean & 1.65 & 0.10 & 337 & 254 & 458 & 277 \\
Standard & 1.25 & 0.06 & 335 & 179 & 462 & 233 \\
deviation & & & & & &
\end{tabular}

Note: average slope gradient (ASG), total feses length (TFL), feses density (FD), total stone bund length (TSL), stone bund density (SBD).

density to study exclusively the impact of land surface management on runoff response.

Runoff analyses revealed two catchments (CA 9 and CA 10) to be erratic as more than $80 \%$ of the runoff events show runoff coefficients (RCs) exceeding $100 \%$ and runoff peak values are found to be outliers. For these reasons both catchments were excluded from runoff analyses, though kept for further analyses on on-site soil erosion. Possible sources of error are: (1) underestimation of the area contributing to runoff; (2) the assumption of uniform flow at the outlet; (3) erratic field measurements of the slope gradient at the outlet channels; (4) erratic field measurements of the routine flow depths; (5) underestimation of rainfall depth as local events in the catchment area were not all captured. Although the latter is not very likely because rainfall was found to be equally distributed over the study area.

Feses in the Kizin and Wonzima catchments are established using the maresha ard plough, drawn by a pair of oxen (Nyssen et al., 2010b); they have a mean top width of $27 \pm 9 \mathrm{~cm}(N=41)$; a mean depth of $12 \pm 2 \mathrm{~cm}(N=37)$; are made at an average angle with the contour of $44.7^{\circ} \pm 7.2^{\circ}(\mathrm{N}=96)$; and a mean gradient of $0.055 \pm 0.054 \mathrm{~m} \mathrm{~m}^{-1}(\mathrm{~N}=96)$ (Monsieurs et al., 2015a).
Feses are constructed on places where runon water accumulates, independently from the type of crops grown in the field plots where the feses are made. Also in other parts of Ethiopia, topography is a determining factor for the construction of the drainage ditches as it controls where runoff is concentrating (Million, 1996; Gessesse, 2014). If possible, feses are constructed with their outlet towards a common pathway. The depth of the feses is chosen in such a way that the farmer is able to plough and destroy the feses the following year. Feses are perceived by the local farmers as the best physical soil conservation technique when stone bunds are lacking. However, all farmers are aware of their negative implications as well. Feses constructed perpendicular to the contour are perceived by most farmers as mismanagement of the farmland as they lead to intense soil erosion in the feses, turning them into ephemeral gullies. Each year, locations of the feses within a farmer's plot are changed, to prevent long-term erosion at these sites.

\section{Materials and Methods}

\section{Rainfall measurements}

Rain gauges, similar to the National Meteorological Services Agency (NMSA) gauge in Wanzaye were installed in Gedam and Tashmender villages from 15 July 2013 to 4 September 2013 (Figure 1). They have been enclosed by a fence to protect them from disturbing factors and a minimum distance of $3 \mathrm{~m}$ to any kind of obstacles, including trees, was kept. Secondary school students have been trained to record every evening (daytime precipitation) and every morning (night-time precipitation) at 07:00 and 18:00 (GMT + 3), the volume of water in the rain gauge using a graded cylinder. Their records were regularly checked for their quality and precision to minimize data errors. Rainfall data from rain gauges in Gedam and Tashmender have been attributed to the subcatchments located within the rain gauge's catchment.

\section{Rill erosion measurements}

According to Zegeye et al. (2010), the maximum rill development (number and dimensions) in the Debre Mewi watershed 
in the Lake Tana basin is attained in August. Hence, rill erosion in the study area has been measured at the end of August 2013. Analyses are based on the calculated rill volumes, because these volumes comprise all dimensions of the rill (length, depth, width), rather than on rill density (in $\mathrm{m} \mathrm{ha}^{-1}$ ) as this only comprises the rill length (Zegeye et al., 2010). The rill volume was measured from its starting point up to the point where the eroded soil was deposited by measuring the length, width and depth. Depth and width of the rills were measured at a point along the rill being representative for the entire rill. Rill width was measured at half depth of the rill to represent the mean width and to approach the cross-section as a trapezium which best reflects the field conditions. Total rill volume per area (TRA; in $\mathrm{m}^{3} \mathrm{ha}^{-1}$ ) was calculated as the sum of the volume of each rill (in $\mathrm{m}^{3}$ ) in a catchment divided by the catchment area (in hectares). Soil loss by rill erosion (in ton $\mathrm{ha}^{-1}$ ) was calculated by multiplying the catchment-averaged measured bulk density with the total rill volume per ha. Soil samples were taken in the topsoil layer with Kopecky core rings $\left(100 \mathrm{~cm}^{3}\right)$ three times throughout the rainy season at two fixed sites per catchment for determining bulk density.

\section{Runoff discharge calculations}

Runoff discharge calculations at the catchment outlet were based on routine flow depth measurements and rating curves. A data collector for each catchment was trained to conduct routine flow depth measurements, i.e. recording for every daytime rainfall event runoff depth measured with a graded ruler at the outlet channel with an interval of five minutes. Routine flow depths are converted to continuous runoff discharge series by a rating curve (Descheemaeker et al., 2008; Nyssen et al., 2010a; Rodriguez-Blanco et al., 2013):

$$
Q=a h^{b}
$$

where $Q$ (in $\mathrm{m}^{3} \mathrm{~s}^{-1}$ ) is discharge, $h$ (in metres) is the flow depth and $a$ and $b$ are fitting parameters. Discharges for different flow depths were calculated using the Manning formula (Manning, 1891), assuming uniform flow, and expert-based estimations of their Manning coefficient $n$. The cross-sectional area and wetted perimeter for these flow depths were calculated using a two-dimensional (2D) drawing program (DraftSight) after detailed recording of the cross-section for each outlet. Subsequently, rating curves in the form of Equation (1) could be constructed for all catchments. The procedure for estimating the roughness coefficient in the Manning formula is generally subjective for which the accuracy depends on the applicants' experience (Coon, 1995). To decrease the subjectivity, eight scientists (geomorphologists) of the Ghent and Bahir Dar Universities who are familiar with the Manning formula and its parameters have been asked to give their estimation for Cowan's parameters (Cowan, 1956) determining the roughness coefficient based on photographs of the outlet channel. We took the mean of the estimates for each parameter to estimate the roughness coefficient $n$.

For each rainfall event, peak flow discharge $\left(Q_{p}\right)$, total runoff (in millimetres), and runoff coefficient (RC, \%) were calculated. The $\mathrm{RC}$ was calculated as a fraction of the measured daytime rainfall, resulting in underestimations of the RC if daytime rainfall comprised rainfall event(s) prior to or after the runoff measurement.

\section{Hydrograph characteristics}

Hydrographs were plotted for the measured runoff events, and their shape compared for the different catchments. For the calculation of the hydrograph peakedness (kurtosis, VRT, and QBT) only the events that have been measured from the beginning up to the end, i.e. rising and falling limb are captured, were incorporated. Continuous percolating baseflow through the channels has not been taken into account as the discharge was negligible compared to storm runoff discharge. The kurtosis is a measure of the peakedness of the hydrograph histogram (Hood et al., 2007). A minimum value of the kurtosis is -3 , for which the histogram is flat; a graph with a kurtosis of zero is normally distributed; and a graph with a kurtosis higher than zero (until infinity) is more sharp than if it was normal distributed. In general, 'a low-kurtosis hydrograph has a broad, low-amplitude peak, is more rounded and has a shorter tail' and 'a high-kurtosis distribution has a sharper peak and longer, fatter tails' which reflects a flash flow regime (Fryirs and Brierley, 2012). Furthermore, we developed an index for the increase of runoff discharge during a period of 10 minutes before the peak was reached, normalized for daily rainfall and the catchment area:

$$
\mathrm{VRT}=\frac{Q_{p}-Q_{t}}{P A}
$$

where $Q_{t}$ is discharge at $t$ minutes before $Q_{p}$, both normalized by daytime rainfall ( $P$, in millimetres) at the date of the runoff event and catchment area $\left(A\right.$, in $\left.\mathrm{m}^{2}\right)$. For $Q_{t}, t=10$ minutes was used because data at a time longer than 10 minutes before $Q_{p}$ was not always available. QBT is another measure of hydrograph peakedness calculated as the peak flow discharge to base time ratio. The base time is the duration of direct runoff production in the hydrograph considered (Gregory and Walling, 1968; Gordon et al., 2004). For detailed analyses we prefer the kurtosis above the use of VRT or QBT as a measure of the hydrograph peakedness for the following reasons: (1) VRT is only a measure for peakedness during rise time and does not comprise the data of the falling limb of the hydrograph; (2) VRT is limited by $t=10$ minutes for $Q_{t}$ for the data of the study area; (3) base time used for QBT is not accurate as runoff events could not always be totally captured; (4) kurtosis is widely used as a measure for hydrograph peakedness (Hood et al., 2007; Kumar and Chatterjee, 2005; Tardif et al., 2009; Graf, 2010; Fryirs and Brierley, 2012). Also the peak flow discharge will be used as a measure for peakedness, which has been normalized by the catchment area $\left(Q_{\mathrm{p}} A^{-1}\right)$, enabling a comparison between the study areas.

\section{Results}

\section{Rainfall characteristics}

Pluviograms for rain gauges in Gedam, Tashmender and Wanzaye (rain gauge of the NMSA) are presented in Figure 2. Independent samples t-tests in SPSS showed no significant difference in the distribution of daily and monthly rainfall depths for these three rain gauges. Hence, we assume that rainfall was equally distributed over the whole study area during the research period. Mean rainfall depth around Wanzaye during the period of fieldwork in 2013 for (15-31) July was $372.35 \pm 5.78 \mathrm{~mm}$, for (1-31) August 377.03 $\pm 4.77 \mathrm{~mm}$ and for (1-4) September $66.02 \pm 5.15 \mathrm{~mm}$. Variations are calculated as standard deviations, also for further analyses. When comparing August 2013 to the 20-year mean (1992-2012) precipitation measured by the NMSA in Bahir Dar (i.e. $387.2 \pm 110.1 \mathrm{~mm}$ ), 2013 seems not an exceptional year regarding precipitation. 


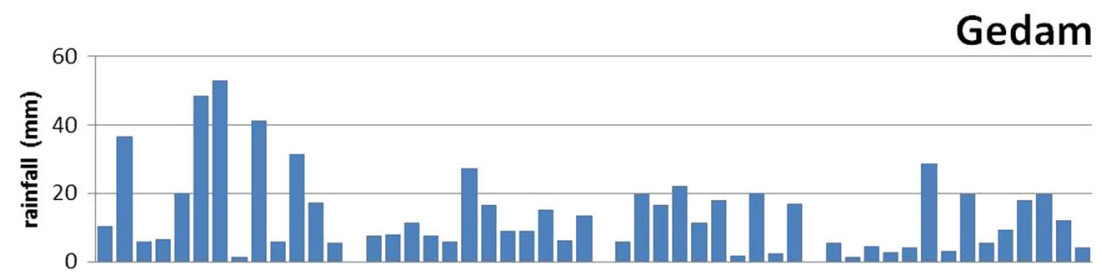

Tashmender
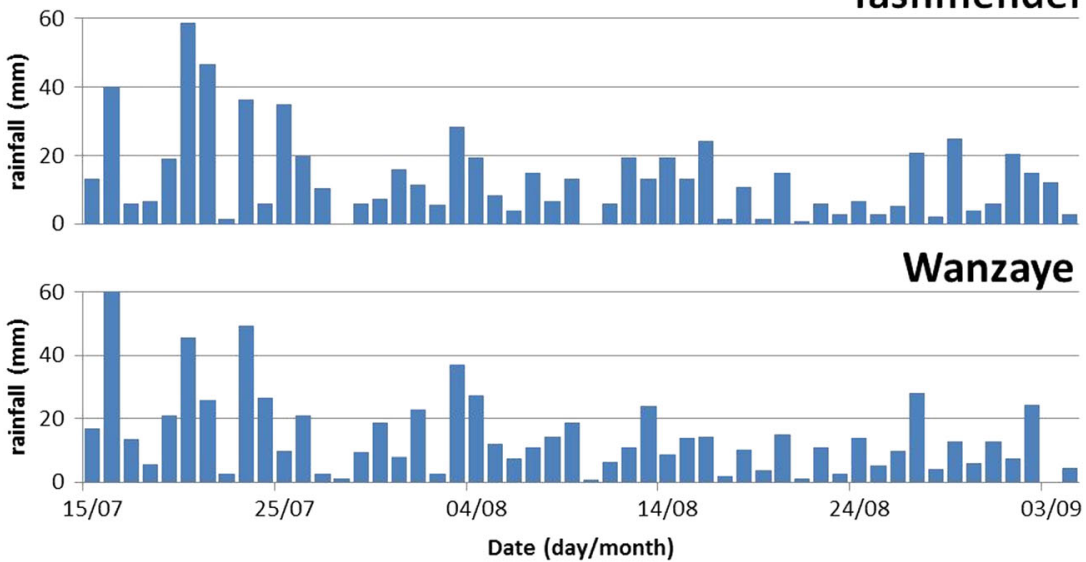

Figure 2. Pluviograms for three rain stations during the rainy season of 2013 around Wanzaye (Ethiopia). This figure is available in colour online at wileyonlinelibrary.com/journal/espl

\section{Environmental conditions during fieldwork}

Catchment-averaged soil depths range from $0.17 \mathrm{~m}$ to $0.77 \mathrm{~m}$. Mean soil depth for all catchments is $0.42 \pm 0.20 \mathrm{~m}$ $(N=39)$. The study area around Wanzaye was found to be very stony with an overall surface rock fragment cover of $66.7 \pm 26.1 \% \quad(N=38)$. To check whether the average soil moisture content for the successive soil sampling campaigns changed over time, a repeated measures analysis of variance (ANOVA) test in SPSS was performed. We found no significant effect (significance level $\alpha=0.05$ ) of sampling moment on gravimetric soil moisture content, i.e. the antecedent soil moisture conditions remained similar during the research period. Measured dry bulk densities ranged from $1.31 \mathrm{~g} \mathrm{~cm}^{-3}$ (CA 2) to $1.74 \mathrm{~g} \mathrm{~cm}^{-3}$ (CA 1). The total average (time- and space-averaged) dry bulk density is $1.56 \pm 0.11 \mathrm{~g} \mathrm{~cm}^{-3}(N=60)$, which is high compared to bulk density values from other studies in Ethiopia (Nyssen et al., 2000; Descheemaeker et al., 2006; Mekuria et al., 2012).

Table II shows the correlations between SBD, feses density (FD), surface rock fragment cover, soil depth, catchment slope gradient, angle between established feses and the contour, and feses gradient. A negative correlation was found between SBD and FD $(R=-0.72 *, N=10$; *refers to its significance at $\alpha=0.05$ also for the figures hereafter), which is a government policy that forbids making feses where stone bunds were constructed at governmental initiative (Monsieurs et al., 2015b). The following relationship for feses density and stone bund density (both in $\mathrm{m} \mathrm{ha}^{-1}$ ), has been established:

$$
\mathrm{FD}=409-0.558 \mathrm{SBD} \quad R^{2}=0.52, N=10
$$

Both the slope (i.e. the coefficient for SBD) and the intercept are significant $(\alpha=0.05)$. SBD explains $52 \%$ of the variability in FD. No other landscape elements from Table II could be found to explain the variability of FD.

FD and soil depth are negatively correlated $(R=-0.40$, $N=10$ ), which can be attributed to the fact that soil depth affects the water retention properties (Kassa et al., 2010) as shallow soils get saturated more quickly causing runoff by saturation excess (e.g. Martinez-Mena et al., 1998; Liu et al., 2008). Hence we assume that feses are made to avoid a saturated topsoil on shallow soils. Though we should be cautious when interpreting these findings because the catchments selected for our analyses were mainly situated in the hills, hence having relatively shallow soils that get easily saturated. Yet, feses are also made in deep (mainly clay) soils located in more gently sloping areas for which several studies indicate that the valley bottoms are common places of saturation by excess runoff (Engda et al., 2011; Dagnew et al.,

Table II. Correlation $(R)$ matrix between stone bund density ( $\mathrm{SBD}$, in $\mathrm{m} \mathrm{ha}^{-1}$ ); feses density (FD, in $\mathrm{m} \mathrm{ha}^{-1}$ ); surface rock fragment cover (Stone, \%); soil depth (s_depth, in metres); dry soil bulk density (BD, in $\mathrm{g} \mathrm{cm}^{-3}$ ); catchment slope gradient (c_gradient, in $\mathrm{m} \mathrm{m}^{-1}$ ); angle between established feses and the contour (f_contour, in degrees); and feses gradient (f_gradient, in $\mathrm{m} \mathrm{m}^{-1}$ )

\begin{tabular}{|c|c|c|c|c|c|c|c|}
\hline & FD & Stone & s_depth & $\mathrm{BD}$ & C_gradient & f_contour & f_gradient \\
\hline SBD & $-0.72 *$ & 0.21 & -0.05 & 0.15 & -0.17 & $0.75^{*}$ & 0.28 \\
\hline FD & & 0.15 & -0.40 & -0.13 & 0.37 & $-0.67^{*}$ & -0.04 \\
\hline Stone & & & $-0.79^{*}$ & -0.50 & $0.68^{*}$ & 0.03 & 0.34 \\
\hline s_depth & & & & 0.52 & $-0.64^{*}$ & 0.10 & -0.30 \\
\hline $\mathrm{BD}$ & & & & & -0.19 & 0.51 & 0.30 \\
\hline C_gradient & & & & & & -0.12 & 0.55 \\
\hline f_contour & & & & & & & 0.30 \\
\hline
\end{tabular}

Significant correlations for $\alpha=0.05$ are marked by an asterisk ( *significant at $\alpha=0.05$ ). All correlations are based on 10 observations. 
2015). Despite the consensus on the fact that surface rock fragment cover protects cropland from soil erosion by water (e.g. Wischmeier and Smith, 1978; Poesen et al., 1994; Nyssen et al., 2001, 2007), a strong negative correlation is found in the study area between soil depth and surface rock fragment cover $(R=-0.79 *, \quad N=10$; Monsieurs et al., 2015a). This correlation is the result of the underlying correlation between rock fragment cover and catchment slope gradient $\left(R=0.68^{*}, N=10\right.$; Monsieurs et al., 2015a), as thin soils occur on steep slopes (e.g. Poesen et al., 1998; Hopp and McDonnell, 2009; Easton et al., 2010). The latter was confirmed for our study area where the catchment slope gradient is negatively correlated with soil depth $(R=-0.64 *$, $N=10$; Monsieurs et al., 2015a). The correlations between $\mathrm{SBD}, \mathrm{FD}$ and the angle of the feses with the contour reveal contrasting behaviours, i.e. SBD being highly positive correlated $\left(R=0.75^{*}, N=10\right)$, and FD highly negative correlated $\left(R=-0.67^{*}, N=10\right)$ to the angle between the feses and the contour.

\section{Rill volumes correlated with environmental conditions}

The TRA (in $\mathrm{m}^{3} \mathrm{ha}^{-1}$ ) and total soil loss per area (in ton ha ${ }^{-1}$ ), that occurred by the end of August, varies over the 10 study areas (Table III). A maximum TRA and soil loss per hectare was found for CA $10\left(13.19 \mathrm{~m}^{3} \mathrm{ha}^{-1} ; 19.66\right.$ ton ha $\left.{ }^{-1}\right)$ and a minimum for CA $2\left(0.17 \mathrm{~m}^{3} \mathrm{ha}^{-1}, 0.25\right.$ ton ha $\left.{ }^{-1}\right)$. The mean volume of rill erosion per hectare for all catchments was 3.73 $\pm 4.20 \mathrm{~m}^{3} \mathrm{ha}^{-1}$ and the mean corresponding soil loss was $5.72 \pm 6.30$ ton $\mathrm{ha}^{-1}$. TRA comprises all rills in the 10 catchment whereas for further analyses, only rills for which the origin of the rill formation was clearly visible in the field, as illustrated in Figures $3 \mathrm{~A}$ and $3 \mathrm{~B}$, have been categorized. A distinction has been made for rills which were formed by stone bunds or feses overflow, i.e. runoff flowing over the feses banks. Also rills formed on a thin soil layer or plough pan were visible in the field (Figures 3C and 3D) yet will not be further analysed as this is out of the scope of this paper. For all 10 catchments, $41 \%$ of the formed rills were initiated by feses, in contrast to $16 \%$ by stone bunds.

SBD and TRA are negatively correlated $(R=-0.50, N=10$; Table IV), whereas the correlation between FD and TRA is positive $(R=0.59, N=10$; Table IV). Rill erosion in a feses catchment is illustrated in Figure 4. TRA showed strong correlations with catchment slope gradient $(R=0.54, N=10)$ and soil depth $(R=-0.46, N=10)$.

Table III. Total rill volume per hectare (TRA) (in $\mathrm{m}^{3} \mathrm{ha}^{-1}$ ) and the total soil loss (in ton $\mathrm{ha}^{-1}$ ) for the 10 cropland catchments (CA)

\begin{tabular}{lrc}
\hline CA & TRA $\left(\mathrm{m}^{3} \mathrm{ha}^{-1}\right)$ & Total soil loss $($ ton ha \\
\end{tabular}

\section{Runoff response for different land management} systems

\section{Runoff depth and runoff coefficients}

Over CA 1 to CA 8, the Manning roughness coefficient rated by a team of geomorphologists ranged from 0.043 (CA 8) to 0.089 (CA 2) (Figure 5) and the mean $n$ is $0.061 \pm 0.017$.

The calculated runoff depth for all measured daytime runoff events in the eight catchments are summarized in Table V. Average of the sum of daytime runoff for 15-31 July was $13.0 \pm 17.1 \mathrm{~mm}$, for 1-31 August $19.4 \pm 12.0 \mathrm{~mm}$ and for $1-4$ September $5.4 \pm 7.9 \mathrm{~mm}$ for all study catchments around Wanzaye. Variations in runoff will be discussed by the variation in RCs. An example for the runoff events measured on 14 August is illustrated by hydrographs in Figure 6. Rainfall depth measured that day was $20.9 \mathrm{~mm}$. For CA 6 and CA 7(2), data might not have been gathered from the beginning of the runoff event. Peak flow discharges for these runoff events ranged from $0.003 \mathrm{~m}^{3} \mathrm{~s}^{-1}$ for CA $7(2)$ to $0.15 \mathrm{~m}^{3} \mathrm{~s}^{-1}$ for CA 3.

RCs for all measured runoff events in the eight catchments are summarized in Table V. A minimum mean RC was found for CA $2(5.1 \%)$ and a maximum for CA $3(38.8 \%)$. The mean RC over all study areas is $21.7 \pm 9.8 \%$. Independent samples t-tests in SPSS show that RCs of CA 2 are significantly smaller than all other catchments. FD is found to be positively correlated with $\mathrm{RC}(R=0.48, N=8)$ in contrast with SBD which is negatively correlated with the RC $(R=-0.18, N=8)$.

\section{Runoff hydrographs}

A summary of the normalized peak flow discharge, kurtosis, VRT and QBT for all measured runoff events is presented in Table VI. For CA 1, 13 out of 14 events were not captured from the beginning, thus no statistics could be made for this catchment. The kurtosis for the individual hydrographs varied for different events and for different catchments. Contrasting values for kurtosis of the hydrographs for runoff events on 14 August are shown in Figure 6 where the maximum value in Figure 6 was found for CA 3 (3.76) and a minimum for CA 7(1) (-0.80).

High positive correlations are found between the three hydrograph peakedness measures: kurtosis, VRT and QBT (Table VII). The same trends are visible for these measures: hydrograph peakedness is negatively correlated with SBD and positively correlated with FD. Also for the normalized peak flow discharge the same tendency is found with SBD and FD (Table VII).

To understand the impact of feses and stone bunds on the erosion processes, a relation for kurtosis representing peakedness has been sought, as channel erosion and sediment transport will be higher when the peak runoff discharge increases (Simon and Rinaldi, 2006). Models where SBD and FD were used separately have a lower $R^{2}$ or are not significant respectively. Highest significance was found using a multiple regression for kurtosis $(k)$ :

$$
\begin{aligned}
& k=-0.002 \mathrm{FD}-0.005 \mathrm{SBD}+1.80 \\
& \left(R^{2}=0.826, N=7, p=0.03\right)
\end{aligned}
$$

This regression is significant $(\alpha=0.05)$ and FD and SBD are explaining $83 \%$ of the kurtosis variability.

\section{Discussion}

Effect of surface drainage by feses and stone bunds on rill erosion

From the observations and the discussions with the farmers around Wanzaye, we understand that the establishment of feses consists of striking a balance between the feses' impact on erosion and their soil protecting effects. Farmers perceive 

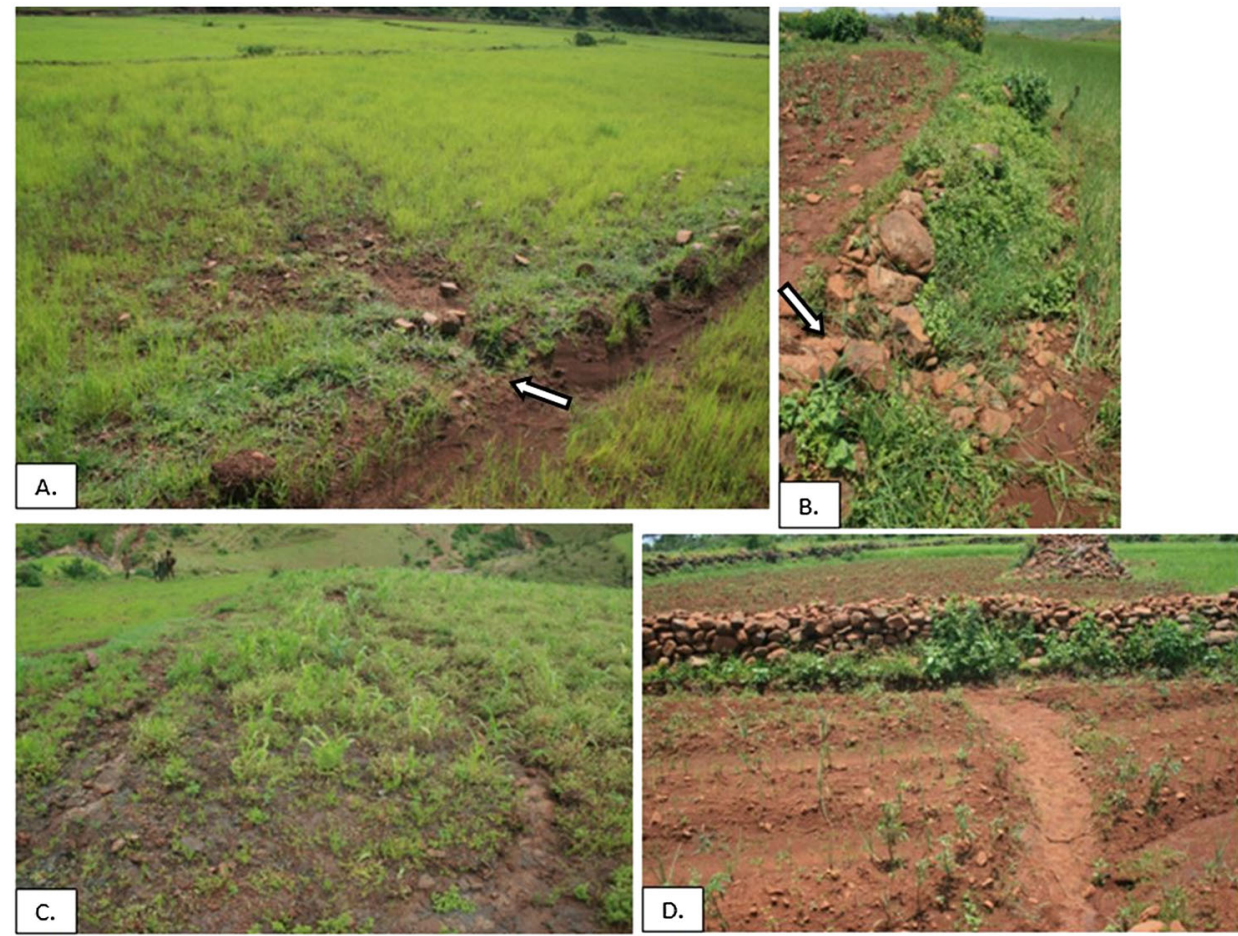

Figure 3. Rill formation originating from feses (A) or stone bund (B) overflow, and on a thin soil layer (C) or plough pan (D) around Wanzaye (Ethiopia). Overflow causing rill formation is indicated by an arrow. This figure is available in colour online at wileyonlinelibrary.com/journal/espl

Table IV. Correlation $(R)$ between total rill volume per area (TRA, in $\mathrm{m}^{3} \mathrm{ha}^{-1}$ ) and stone bund density ( $\mathrm{SBD}$, in $\mathrm{m} \mathrm{ha}^{-1}$ ); feses density (FD, in $\mathrm{m} \mathrm{ha}^{-1}$ ); surface rock fragment cover (stone, \%); soil depth (s_depth, in metres); dry soil bulk density (BD, in $\mathrm{g} \mathrm{cm}^{-3}$ ); catchment slope gradient (c_gradient, in $\mathrm{m} \mathrm{m}^{-1}$ ); angle between established feses and the contour (f_contour, in degrees); and feses gradient (f_gradient, in $\mathrm{m} \mathrm{m}^{-1}$ ). All correlations are based on 10 observations

TRA

\begin{tabular}{lr}
\hline SBD & -0.50 \\
FD & 0.59 \\
stone & 0.26 \\
S_depth & -0.46 \\
BD & -0.25 \\
C_gradient & 0.54 \\
f_contour & -0.53 \\
f_gradient & -0.27 \\
\hline
\end{tabular}

the construction of feses at a large angle with the contour as a mismanagement of the land as the feses are then eroded fast and become rills or even gullies. Whereas, a strong negative correlation was found between the angle of the constructed feses with the contour and the total rill erosion volume $\mathrm{ha}^{-1}(R=-0.53, \mathrm{~N}=10$; Table IV), implying that feses at a small angle with the contour induce more rill erosion volume due to overflowing water. This was also confirmed by the number of rills initiated by feses. We observed a strong positive correlation between the angle of the constructed feses with the contour and SBD $\left(R=0.75^{*}\right.$, $N=10)$, whereas this correlation is highly negative for FD $\left(R=-0.67^{*}, N=10\right)$. This implies that if SBD is higher, feses are constructed at a larger angle with the contour. In contrast, if the FD is higher, feses are constructed at a smaller angle with the contour. This may be due to the fact that stone bunds are perceived by farmers as a good SWC tool, and a high FD is estimated to be sufficient in runoff evacuation even at lower gradients.
A strong positive correlation between TRA and FD has been found ( $R=0.59, N=10$; Table IV). By contrast, a negative correlation between TRA and SBD $(R=-0.50, N=10$; Table IV) for the 10 studied cropland catchments was obtained. It shows a clear distinct trend for both SWC practices: feses cause larger rill volumes than stone bunds. This is confirmed by the fraction of rills initiated by feses $(41 \%)$, which is higher than that for stone bunds (16\%). Also farmers are aware of rill erosion, although they conclude that feses are still the best way to avoid soil erosion when no stone bunds are present.

The soil loss calculated for the study area (Table III) can only be compared with values for exclusively rill erosion in other studies, as our values would be underestimations compared to the total soil loss which also includes soil losses by interrill erosion. The TRA are low compared to those found by Bewket and Sterk (2003) on cultivated fields in the north-western highlands of Ethiopia. They measured $22.5 \mathrm{~m}^{3} \mathrm{ha}^{-1}$ rill volume for a catchment with gentle slopes and $55.5 \mathrm{~m}^{3} \mathrm{ha}^{-1}$ rill volume for a catchment with steep slopes whereas we measured a mean TRA of $3.73 \pm 4.20 \mathrm{~m}^{3} \mathrm{ha}^{-1}$ (Table III). Zegeye et al. (2010) found an average soil loss by sheet and rill erosion of 27 ton ha $^{-1}$ in the Debre Mewi watershed (part of the Lake Tana basin), while the maximum soil loss found around Wanzaye is 19.66 ton $\mathrm{ha}^{-1}$ by rill erosion only. More comparable values have been found by Awulachew et al. (2010) who conducted a Soil and Water Assessment Tool (SWAT) based runoff and sediment yield model analysis for the Gumara catchment. They produced a map of 18 sub-basins in the Gumara watershed for which the averaged sediment yields were presented ranging from 0 to 22 ton $\mathrm{ha}^{-1} \mathrm{yr}^{-1}$. Wanzaye is situated in a sub-basin producing on average 6 to 10 ton $\mathrm{ha}^{-1} \mathrm{yr}^{-1}$. Nyssen et al. (2008) found in the northern Ethiopian Highlands an averaged measured soil loss by sheet and rill erosion on cropland of $9.9 \pm 13.2$ ton $\mathrm{ha}^{-1} \mathrm{yr}^{-1}$, which is below the Ethiopian average, i.e. 42 ton $\mathrm{ha}^{-1} \mathrm{yr}^{-1}$ (Hurni, 1990). This wide range of soil loss by rill erosion found in the Ethiopian Highlands originates from the site specific variables controlling the amount of rill erosion: e.g. surface rock fragment content (Nyssen et al., 2001); SWC practices (Zegeye et al., 2010, Taye et al., 2013); depth and intensity of rain (Nyssen et al., 


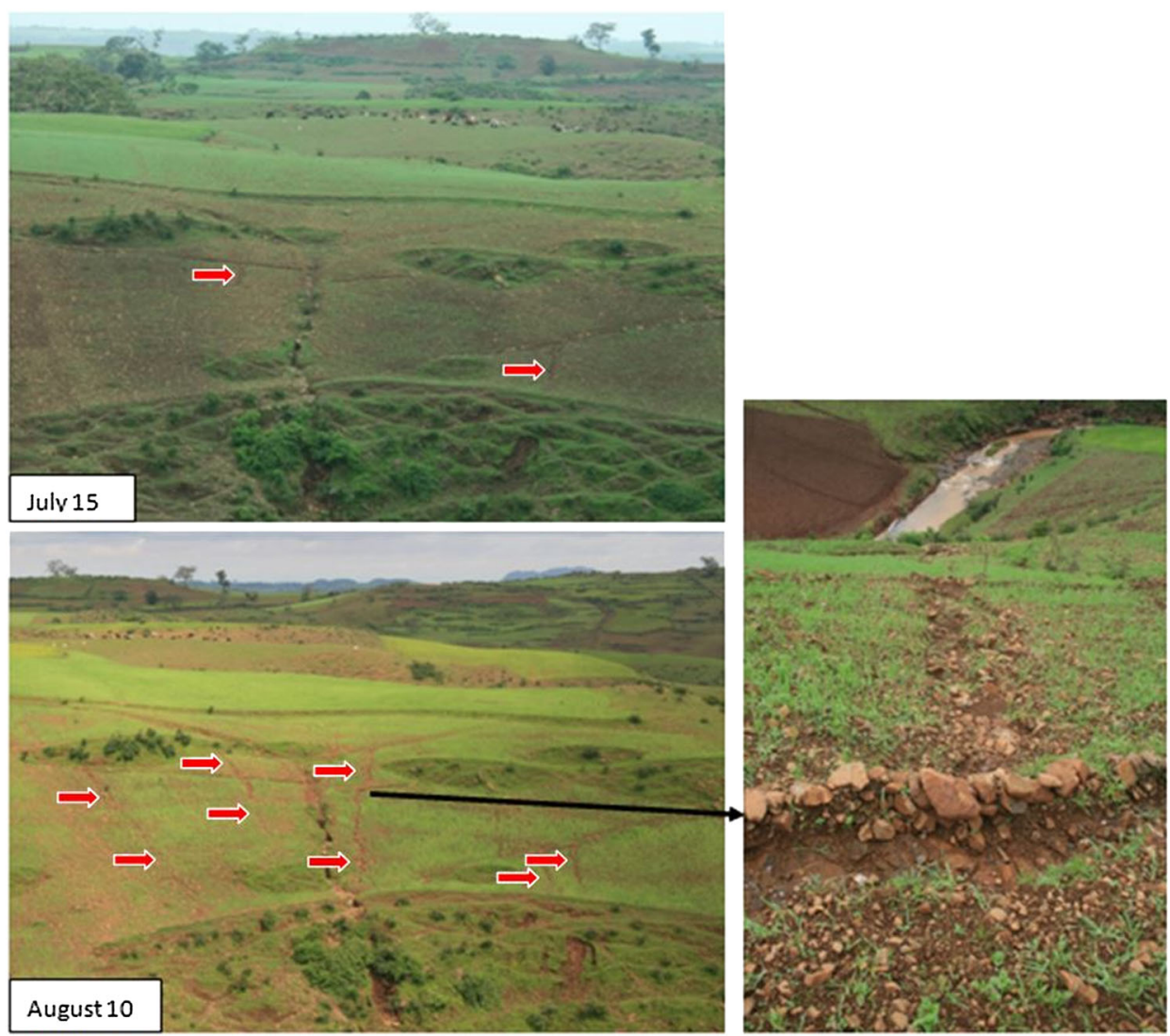

Figure 4. Feses catchment on 15 July 2013 (upper) when only two small rills are present (indicated with a red arrow). On 10 August 2013 (lower), several new rills have developed in this catchment. The farmer has restored the feses by removing sediment from the feses and by reconstructing the feses' edge with stones and soil (Wanzaye, Ethiopia). This figure is available in colour online at wileyonlinelibrary.com/journal/espl

\section{CATCHMENT 8: $\mathrm{n}=\mathbf{0 . 0 4 3}$}

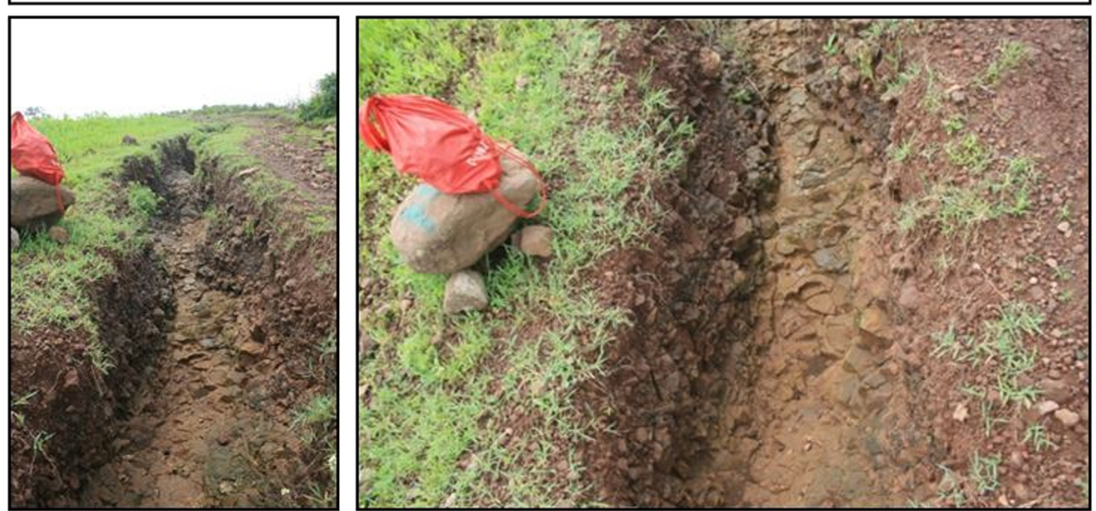

\section{CATCHMENT 2: $n=0.089$}
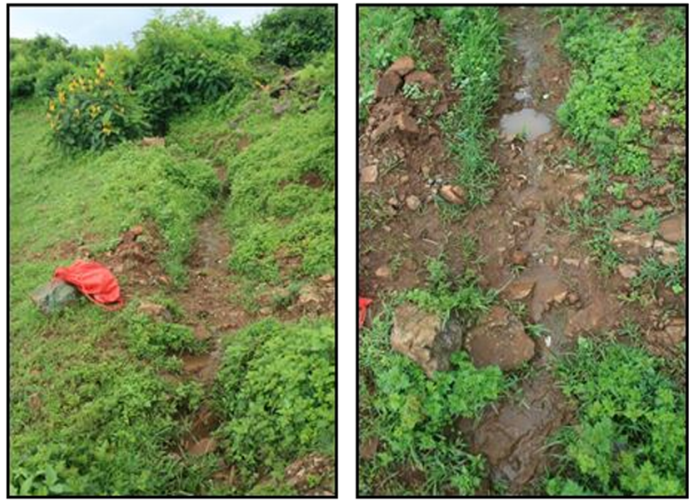

Figure 5. Illustration of minimum (CA 8) and maximum (CA 2) Manning roughness coefficient ( $n$ ) among the eight study catchments around Wanzaye (Ethiopia). Left: oblique view; right: plan view of the main channel. Approximate dimensions (height $\times$ length) of the red bag are $50 \mathrm{~cm} \times 25 \mathrm{~cm}$. This figure is available in colour online at wileyonlinelibrary.com/journal/espl 
Table V. Total measured daytime runoff depth (DR) in summer 2013 around Wanzaye (Ethiopia) for (1) 15-31 July, (2) 1-31 August and (3) 1-4 September in the eight studied cropland catchments (CA). Mean event-based runoff coefficient (RC), and the statistics for each of these catchments are shown in the right part: number of observations $(\mathrm{N})$, standard deviation (SD), minimum (Min) and maximum (Max) runoff coefficient

\begin{tabular}{|c|c|c|c|c|c|c|c|c|}
\hline & \multicolumn{3}{|c|}{$\mathrm{DR}(\mathrm{mm})$} & \multirow[b]{2}{*}{ RC (\%) } & \multirow[b]{2}{*}{$N$} & \multirow[b]{2}{*}{ SD } & \multirow[b]{2}{*}{ Min } & \multirow[b]{2}{*}{ Max } \\
\hline & (1) & (2) & (3) & & & & & \\
\hline CA 1 & 32.5 & 15.3 & 10.9 & 28.8 & 16 & 23.1 & 0.5 & 74.2 \\
\hline CA 2 & 1.4 & 5.0 & 0.4 & 5.1 & 16 & 4.1 & 0.2 & 13.7 \\
\hline CA 3 & 46.8 & 35.0 & 0.0 & 38.8 & 13 & 22.8 & 14.1 & 73.6 \\
\hline CA 4 & 4.9 & 14.1 & 4.6 & 19.2 & 13 & 9.3 & 4.5 & 39.6 \\
\hline CA 5 & 9.0 & 33.8 & 22.8 & 24.6 & 17 & 16.5 & 5.8 & 62.9 \\
\hline CA 6 & 0.4 & 14.5 & 1.1 & 17.6 & 11 & 16.3 & 2.3 & 59.0 \\
\hline CA 7 & 3.8 & 7.0 & 1.5 & 12.6 & 12 & 8.8 & 2.7 & 28.6 \\
\hline CA 8 & 4.8 & 30.6 & 2.1 & 27.0 & 12 & 25.9 & 1.1 & 82.8 \\
\hline Min & 0.4 & 5.0 & 0.0 & 5.1 & & & & \\
\hline Max & 46.8 & 35.0 & 22.8 & 38.8 & & & & \\
\hline Mean & 13.0 & 19.4 & 5.4 & 21.7 & & & & \\
\hline SD & 17.1 & 12.0 & 7.9 & 9.8 & & & & \\
\hline
\end{tabular}

2005); soil types (Barthès and Roose, 2002); and geomorphology (Billi and Dramis, 2003). For the area around Wanzaye, we believe that two factors explain the relatively low soil loss by rill erosion: (1) a high surface rock fragment cover, and (2) the applied SWC practices which seem to have a positive effect on the rate of rill erosion. Besides the application of stone bunds in the study area, which is generally perceived as a good management tool for erosion control (Nyssen et al., 2007), also feses are used as an indigenous practice for erosion control. Zegeye et al. (2010) conclude their research on soil erosion in the Lake Tana basin by stating that feses are 'generally effective and should be an integral part of any soil and water management practices proposed by soil conservation designers', p. 305. Hence, both SWC practices around Wanzaye (stone bunds and feses) are approved to be good tools against on-site soil erosion, yet a difference between both is emphasized further in this study.

\section{Analysis of peak runoff response}

An average RC of $59 \%$ has been estimated by Dessie et al. (2015) for the Gumara basin in 2012 and 2013. This is three times the mean RC we measured in 2013 (21.7\%) for the area
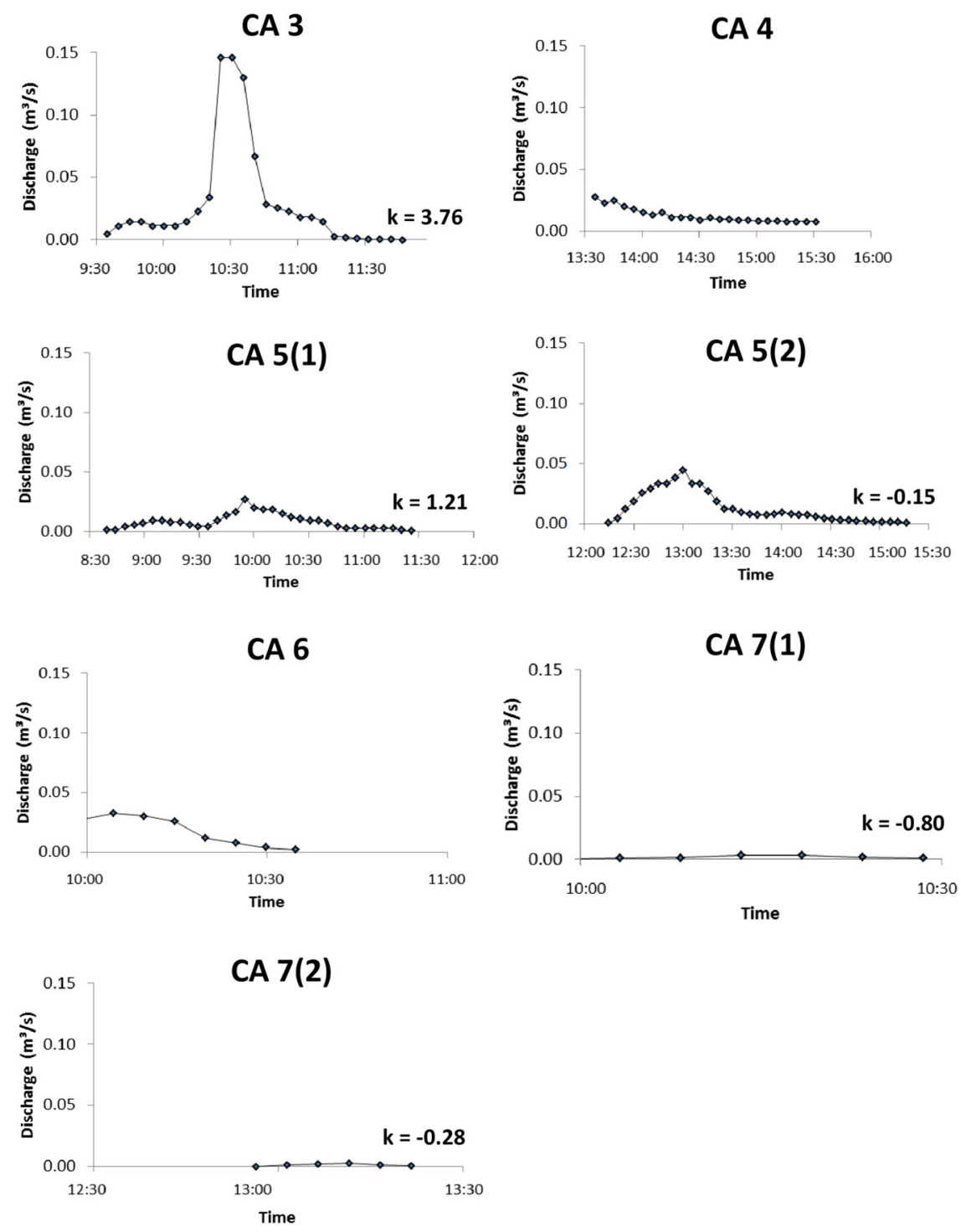

Figure 6. Hydrographs for runoff events measured at the outlets of study areas on 14 August around Wanzaye (Ethiopia). Values for the kurtosis ( $k$ ) of the hydrograph is shown for events where rising and falling limb were captured. 
Table VI. Mean normalized peak flow discharges $\left(Q_{\mathrm{p}} A^{-1}\right.$, in $\left.\mathrm{m} \mathrm{s}^{-1}\right)$ and hydrograph peakedness measures: kurtosis, velocity of rise time (VRT, in $\mathrm{s}^{-1}$ ), and $Q_{\mathrm{p}}$ /base time (QBT, in $\mathrm{m}^{3} \mathrm{~s}^{-1}$ ) for eight subcatchments (CA) around Wanzaye (Ethiopia)

\begin{tabular}{llrll}
\hline & $Q_{\mathrm{p}} A^{-1}$ & kurtosis & VRT & QBT \\
\hline CA 1 & $3.10 \mathrm{E}-06$ & & & \\
CA 2 & $5.20 \mathrm{E}-07$ & -0.31 & $5.75 \mathrm{E}-11$ & 0.020 \\
CA 3 & $6.50 \mathrm{E}-06$ & 1.24 & $3.02 \mathrm{E}-10$ & 0.467 \\
CA 4 & $6.34 \mathrm{E}-07$ & -0.62 & $1.89 \mathrm{E}-11$ & 0.015 \\
CA 5 & $1.38 \mathrm{E}-06$ & -0.36 & $8.62 \mathrm{E}-10$ & 0.014 \\
CA 6 & $1.09 \mathrm{E}-06$ & 0.88 & $7.17 \mathrm{E}-10$ & 0.017 \\
CA 7 & 6.13E-07 & -0.59 & $5.15 \mathrm{E}-11$ & 0.008 \\
CA 8 & $1.58 \mathrm{E}-06$ & 0.13 & $6.00 \mathrm{E}-11$ & 0.008 \\
\hline
\end{tabular}

Table VII. Correlation $(R)$ matrix for stone bund density (SBD), feses density (FD), kurtosis, velocity of rise time (VRT), $Q_{p}$ over base time $(\mathrm{QBT})$, and the normalized peak flow discharge $\left(Q_{p} A^{-1}\right)$. All correlations are based on seven observations

\begin{tabular}{lccccc}
\hline & SBD & FD & kurtosis & VRT & QBT \\
\hline$Q_{p} A^{-1}$ & -0.47 & 0.26 & $0.76^{*}$ & $0.98^{*}$ & $0.98^{*}$ \\
SBD & & -0.61 & -0.67 & -0.54 & -0.50 \\
FD & & & 0.52 & 0.29 & 0.13 \\
kurtosis & & & & $0.76^{*}$ & 0.71 \\
VRT & & & & & $0.98^{*}$ \\
\hline
\end{tabular}

*Significant at $\alpha=0.05$.

around Wanzaye which constitutes the Gumara basin. Different variables explain this discrepancy. First of all, measurements around Wanzaye are event-based during the day. Night-time runoff and continuous baseflow were not measured. When cumulated in time, this slow percolating subsurface water can produce an important volume of runoff that we did not incorporate in our analyses. Our results support the model results of Dessie et al. (2014), which indicate that for the Gumara basin the direct runoff accounts for 18 to $19 \%$ of the total runoff. Also the moment of measuring (i.e. study period falls in an average dry or wet year) matters, as the rainfall conditions (intensity) have an important role concerning runoff generation (Descheemaeker et al., 2006). The mean RC for the study area around Wanzaye was also influenced by the local slope gradients, soil texture, land use, vegetation cover, organic matter and rock fragment cover (Feleke, 1987; Mwendera and Mohammed, 1997), which may explain the lower-thanexpected mean RC.

SWC activities that have taken place over the last decades lowered the RCs in Ethiopia (Nyssen et al., 2010a; Haregeweyn et al., 2015). This is also reflected by the RC for CA 2 which comprises exclusively stone bunds $\left(448 \mathrm{~m} \mathrm{ha}^{-1}\right)$, resulting in a significantly smaller RC $(5.1 \%$, Table V) than that for the other catchments. Yet, when stone bunds are combined with drainage ditches, the RC will be higher as observed for CA 8 with a mean RC of $27.0 \%$, SBD of $626 \mathrm{~m} \mathrm{ha}^{-1}$ and FD of $188 \mathrm{~m} \mathrm{ha}^{-1}$. Although no significant correlation could be found, it seems that a combination of low SBD and high FD results in a higher RC, whereas catchments with a high SBD and low FD have a lower RC. The positive correlation between the $\mathrm{RC}$ and FD indicates that the use of feses induces a higher runoff response.

From the data around Wanzaye, two distinct trends are observed. First of all, hydrograph peakedness decreases when SBD increases. This is an evident result as stone bunds have proven their efficiency in capturing and temporarily storing runoff water in a catchment (e.g. Herweg and Ludi, 1999; Gebremichael et al., 2005; Nyssen et al., 2007; Taye et al., 2013). Conversely, a higher FD results in a higher hydrograph peakedness, which is similar to the natural drainage network (Horton 1932, 1945; Chorley and Morgan, 1962; Gregory and Walling, 1968). Thus we could not confirm the positive effect of the use of drainage ditches on soil water storage capacity as mentioned by, for example, Horton (1945), Thomasson (1975), and Wilkinson et al. (2010). The best model explaining kurtosis of the runoff hydrographs was a multiple regression equation where SBD and FD explain $83 \%$ of its variability (Equation (4)). So by incorporating information of both land management techniques, their effects on the runoff peakedness is best described. Improper land management and hence soil erosion driven by high peak flows can be mitigated whilst an adapted management system is designed taking SBD and FD into account.

\section{Conclusion}

During the rainy season of 2013, the on-site impact of drainage ditches (feses) and stone bunds on rill erosion and runoff characteristics have been measured around Wanzaye (north Ethiopia). We found that the establishment of feses is the result of a balance that the farmers make between the feses' impact on erosion and their soil protecting effect. Stone bunds are an effective SWC technique, which allows feses to be constructed at a greater angle with the contour. On-site rill erosion is larger when feses are present, although feses are perceived as the best way to avoid soil erosion when no stone bunds are present. Mean area-specific volume of rills in the study area equals $3.7 \pm 4.2 \mathrm{~m}^{3} \mathrm{ha}^{-1}$, corresponding to 5.7 \pm 6.3 ton $\mathrm{ha}^{-1}$ of soil loss. The use of feses increases eventbased RCs on cropland from c. $5 \%$ to values up to $39 \%$. Also, a combination of low SBD and high FD results in a higher RC, whereas catchments with a high SBD and low FD have a lower RC. Peak flow discharge decreases when SBD increases, whereas the opposite is found for FD. A multiple linear relation of both land management techniques (feses and stone bunds) performs best in explaining the variability of runoff peakedness $\left(R^{2}=83 \%\right)$. Soil erosion driven by high peak flows can be mitigated whilst a management system is designed taking SBD and FD into account.

Acknowledgements - The authors acknowledge the support of the WaSe-Tana project, a cooperation between Ghent University, KU Leuven, and Bahir Dar University, funded by the Belgian Development Cooperation through VLIR-UOS (VLIR-UOS ZEIN2010PR374-39048). The authors particularly thank the team of hydrologists and geomorphologists for their expert rating of the Manning coefficients. Thanks also go to the VLIR-UOS (VLIR-UOS NREI2013AUG) for funding this study through a travel grant for E.M. Special thanks go to Solomon Mulatie for his dedication as a translator and field assistant, and to Deribew Fente for the technical support. The paper could not have been accomplished without the dedication of the data collectors in the study catchments. Field discussions with farmers in the village around Wanzaye contributed to sharpen the insights into the matter.

\section{References}

Alt S, Jenkins A, Lines KR. 2009. Saving soil - A Landholder's Guide to Preventing and Repairing Soil Erosion. NSW Department of Primary Industry: Orange, NSW.

Amsalu Taye A. 2006. Caring for the Land: Best Practice in Soil and Water Conservation in Beressa Watershed, Highlands of EthiopiaTropical Resource Management Papers. Wageningen Universiteit: Wageningen. 
Amsalu A, de Graaf J. 2007. Determinants of adoption and continued use of stone terraces for soil and water conservation in an Ethiopian highland watershed. Ecological Economics 61(2-3): 294-302. DOI:10.1016/j.ecolecon.2006.01.014.

Armstrong AC, Garwood EA. 1991. Hydrological consequences of artificial drainage of grassland. Hydrological Processes 5(2): 157-174. DOI:10.1002/hyp.3360050204.

Awulachew SB, Ahmed AA, Haileselassie A, Yilma AD, Bashar KE, McCartney M, Steenhuis T. 2010. Improved Water and Land Management in the Ethiopian Highlands and its Impact on Downstream Stakeholders Dependent on the Blue NileCGIAR Challenge Program on Water and Food. International Water Management Institute: Colombo.

Awulachew SB, McCartney M, Steenhuis TS, Ahmed AA. 2008. A Review of Hydrology, Sediment and Water Resource Use in the Blue Nile Basin. Colombo, Sri LankalWMI Working Paper 131. International Water Management Institute (IWMI): Colombo.

Barthès B, Roose E. 2002. Aggregate stability as an indicator of soil susceptibility to runoff and erosion; validation at several levels. Catena 47(2): 133-149. DOI:10.1016/S0341-8162(01)00180-1.

Bewket W, Sterk G. 2003. Assessment of soil erosion in cultivated fields using a survey methodology for rills in the Chemoga watershed. Agriculture, Ecosystems \& Environment 97(1-3): 81-93. DOI:10.1016/S0167-8809(03)00127-0.

Billi P, Dramis F. 2003. Geomorphological investigation on gully erosion in the Rift Valley and the northern highlands of Ethiopia. Catena 50(2-4): 353-368. DOI:10.1016/S0341-8162(02)00131-5.

Bosshart U. 1997. Catchment Discharge and Suspended Sediment Transport as Indicators of Physical Soil and Water Conservation in the Michet CatchmentAnjeni Research Unit. A Case Study in the North-western Highlands of Ethiopia. Soil Conservation Research Project. Research Report 40. Centre for Development and Environment University of Bem: Bern.

Brenner C, Strohmeier S, Ziadat F, Klik A. 2013. Soil Conservation Measures in the Ethiopian Highlands: The Effectiveness of Stone Bunds on Soil Erosion Processes. Paper presented at the EGU General Assembly 2013, Vienna, Austria. Geophysical Research Abstracts, Vol. 15, EGU2013-5392-3.

Carluer N, De Marsily G. 2004. Assessment and modelling of the influence of man-made networks on the hydrology of a small watershed: implications for fast flow components, water quality and landscape management. Journal of Hydrology 285(1): 76-95. DOI:10.1016/j. jhydrol.2003.08.008.

Chorley RJ, Morgan MA. 1962. Comparison of morphometric features, Unaka Mountains, Tennessee and North Carolina, and Dartmoor, England. Geological Society of America Bulletin 73(1): 17-34. DOI:10.1130/0016-7606(1962)73[17:COMFUM]2.0.CO;2.

Colot C. 2012. Soil-Landscape Relation at Regional Scale in Lake Tana Basin (Ethiopia), Unpublished Thesis. Department of Soil and Water Management, KU Leuven.

Conway D. 2000. The climate and hydrology of the Upper Blue Nile River. Geographical Journal 166(1): 49-62.

Conway VM, Millar A. 1960. The hydrology of some small peatcovered catchments in the northern Pennines. Journal of the Institution of Water Engineers 14: 415-424.

Coon WF. 1995. Estimates of Roughness Coefficients for Selected Natural Stream Channels with Vegetated Banks in New YorkUS Geological Survey Open-File Report 93-161. New York State Department of Transportation: Ithaca, NY.

Cowan WI. 1956. Estimating hydraulic roughness coefficients. Agricultural Engineering 37(7): 473-475.

Dagnew DC, Guzman CD, Zegeye AD, Tibebu TY, Getaneh M, Abate S, Zemale FA, Ayana EK, Tilahun SA, Steenhuis TS. 2015. Impact of conservation practices on runoff and soil loss in the sub-humid Ethiopian Highlands: the Debre Mawi watershed. Journal of Hydrology and Hydromechanics 63(3): 210-219. DOI:10.1515/johh-2015-0021.

Dargahi B, Setegn SG. 2011. Combined 3D hydrodynamic and watershed modeling of Lake Tana, Ethiopia. Journal of Hydrology 398(1-2): 44-64. DOI:10.1016/j.jhydrol.2010.12.009.

Descheemaeker K, Nyssen J, Poesen J, Raes D, Haile M, Muys B, Deckers S. 2006. Runoff on slopes with restoring vegetation: a case study from the Tigray highlands, Ethiopia. Journal of Hydrology 331(1): 219-241. DOI:10.1016/j.jhydrol.2006.05.015.
Descheemaeker K, Poesen J, Borselli L, Nyssen J, Raes D, Haile M, Muys B, Deckers J. 2008. Runoff curve numbers for steep hillslopes with natural vegetation in semi-arid tropical highlands, northern Ethiopia. Hydrological Processes 22(20): 4097-4105. DOI:10.1002/hyp.7011.

Dessie M, Verhoest NEC, Pauwels VRN, Admasu T, Poesen J, Adgo E, Deckers J, Nyssen J. 2014. Analyzing runoff processes through conceptual hydrological modeling in the Upper Blue Nile Basin, Ethiopia. Hydrology and Earth System Sciences 18(12): 5149-5167. DOI:10.5194/hessd-11-5287-2014.

Dessie M, Verhoest NE, Pauwels VR, Adgo E, Deckers J, Poesen J, Nyssen J. 2015. Water balance of a lake with floodplain buffering: Lake Tana, Blue Nile Basin, Ethiopia. Journal of Hydrology 522: 174-186. DOI:10.1016/j.jhydrol.2014.12.049.

Easton ZM, Fuka DR, White ED, Collick AS, Ashagre BB, McCartney M, Awulachew SB, Ahmed AA, Steenhuis TS. 2010. A multi basin SWAT model analysis of runoff and sedimentation in the Blue Nile, Ethiopia. Hydrology and Earth System Sciences 14(10): 1827-1841. DOI:10.5194/hess-14-1827-2010.

Engda TA, Bayabil HK, Legesse ES, Ayana EK, Tilahun SA, Collick AS, Easton ZM, Rimmer A, Awulachew SB, Steenhuis TS. 2011. Watershed hydrology of the (semi) humid Ethiopian Highlands. In Nile River Basin, Melesse AM (ed). Springer: Dordrecht; 145-162.

Feleke A. 1987. Effect of vegetative cover, tillage and planting system on run-off, soil erosion and other soil physical properties. Agricultural Mechanization in Asia, Africa and Latin America 18(2): 23-28.

Fryirs KA, Brierley GJ. 2012. Geomorphic Analysis of River Systems: An Approach to Reading the Landscape. Wiley-Blackwell: Oxford.

Gebremichael D, Nyssen J, Poesen J, Deckers J, Haile M, Govers G, Moeyersons J. 2005. Effectiveness of stone bunds in controlling soil erosion on cropland in the Tigray Highlands, northern Ethiopia. Soil Use and Management 21(3): 287-297.

Gessesse GD. 2014. Assessment of soil erosion in the Blue Nile Basin. In Nile River Basin. Springer International Publishing: Cham; 193-218.

Gordon ND, McMahon TA, Finlayson BL, Gippel CJ, Nathan RJ. 2004. Stream Hydrology: An Introduction for Ecologists. Wiley: Chichester.

Graf WL. 2010. Network characteristics in suburbanizing streams. Water Resources Research 13(2): 459-463.

Gregory KJ, Walling DE. 1968. The variation of drainage density within a catchment. International Association of Scientific Hydrology Bulletin 13(V2): 61-68. DOI:10.1080/02626666809493583.

Harden CP. 1992. Incorporating roads and footpaths in watershed-scale hydrologic and soil-erosion models. Physical Geography 13(4): 368-385. DOI:10.1080/02723646.1992.10642463.

Haregeweyn N, Tsunekawa A, Tsubo M, Meshesha D, Adgo E, Poesen J, Schütt B. 2015. Analyzing the hydrologic effects of region-wide land and water development interventions: a case study of the Upper Blue Nile basin. Regional Environmental Change. DOI:10.1007/ s10113-015-0813-2.

Herweg K, Ludi E. 1999. The performance of selected soil and water conservation measures-case studies from Ethiopia and Eritrea. Catena 36(1-2): 99-114. DOI:10.1016/S0341-8162(99)00004-1.

Holden J, Chapman PJ, Labadz JC. 2004. Artificial drainage of peatlands: hydrological and hydrochemical process and wetland restoration. Progress in Physical Geography 28(1): 95-123. DOI:10.1191/0309133304pp403ra.

Hood MJ, Clausen JC, Warner GS. 2007. Comparison of stormwater lag times for low impact and traditional residential development. Journal of the American Water Resources Association 43(4): 1036-1046. DOI:10.1111/j.1752-1688.2007.00085.x.

Hooke JM. 1979. An analysis of the processes of river bank erosion. Journal of Hydrology 42(1-2): 39-62. DOI:10.1016/0022-1694(79) 90005-2.

Hopp L, McDonnell JJ. 2009. Connectivity at the hillslope scale: identifying interactions between storm size, bedrock permeability, slope angle and soil depth. Journal of Hydrology 375(3-4): 378-391. DOI:10.1016/j.jhydrol.2009.07.047.

Horton RE. 1932. Drainage basin characteristics. Transactions American Geophysical Union 13(1): 350-361. DOI:10.1029/TR013i001p00350.

Horton RE. 1945. Erosional development of streams and their drainage basins. Geological Society of America Bulletin 56(3): 275-370. DOI:10.1130/0016-7606(1945)56[275:EDOSAT]2.0.CO;2. 
Hurni H. 1990. Degradation and conservation of soil resources in the Ethiopian Highlands. Mountain Research and Development 8(2-3): 123-130. DOI:10.2307/3673438.

Kassa T, Van Rompaey A, Poesen J. 2010. Land suitability assessment for different irrigation methods in Korir Watershed, northern Ethiopia. Journal of the Drylands 3(2): 214-219.

Kebede S, Admasu G, Travi Y. 2011. Estimating ungauged catchment flows from Lake Tana floodplains, Ethiopia: an isotope hydrological approach. Isotopes in Environmental and Health Studies 47(1): 71-86. DOI:10.1080/10256016.2011.556724.

Kumar R, Chatterjee C. 2005. Regional flood frequency analysis using L-moments for North Brahmaputra region of India. Journal of Hydrologic Engineering 10(1): 1-7.

Liu BM, Collick AS, Zeleke G, Adgo E, Easton ZM, Steenhuis TS. 2008. Rainfall-discharge relationships for a monsoonal climate in the Ethiopian highlands. Hydrological Processes 22(7): 1059-1067. DOI:10.1002/hyp.7022.

Luthin JN. 1966. Drainage Engineering. Wiley: New York.

Manning R. 1891. On the flow of water in open channels and pipes. Transactions of the Institution of Civil Engineers of Ireland 20: 161-207.

Marofi S. 1999. Rôle des échanges nappes-fosses dans le fonctionnement hydrologique d'un bassin versant en milieu méditerrane en cultive, Thèse de I'Ecole Nationale Supérieure Agronomique de Montpellier; $200 \mathrm{pp}$.

Martinez-Mena M, Albaladejo J, Castillo VM. 1998. Factors influencing surface runoff generation in a Mediterranean semi-arid environment: Chicamo watershed, SE Spain. Hydrological Processes 12(5): 741-754.

Mekuria A, Vlek PLG, Denich M. 2012. Application of the caesium137 technique to soil degradation studies in the southwestern Highlands of Ethiopia. Land Degradation \& Development 23(5): 456-464. DOI:10.1002/ldr.1088.

Million A. 1996. Traditional ditches in northern Shewa, Ethiopian highlands. In Sustaining the Soil: Indigenous Soil and Water Conservation in Africa, Reij C, Scoones I, Toulmin CC (eds). IIED: London; 163-169.

Monsieurs E, Dessie M, Adgo E, Poesen J, Deckers J, Verhoest N, Nyssen J. 2015a. Seasonal surface drainage of sloping farmland and its hydrogeomorphic impacts. Land Degradation \& Development 26(1): 35-44. DOI:10.1002/ldr.2286.

Monsieurs E, Poesen J, Dessie M, Adgo E, Verhoest N, Deckers J, Nyssen J. 2015b. Effects of drainage ditches and stone bunds on topographical thresholds for gully head development in north Ethiopia. Geomorphology 234: 193-203. DOI:10.1016/j. geomorph.2015.01.011.

Mwendera E, Mohamed SM. 1997. Infiltration rates, surface runoff, and soil loss as influenced by grazing pressure in the Ethiopian highlands. Soil Use and Management 13(1): 29-35. DOI:10.1111/j.14752743.1997.tb00553.x.

Nyssen J, Clymans W, Descheemaeker K, Poesen J, Vandecasteele I, Vanmaercke M, Zenebe A, Van Camp M, Haile M, Haregeweyn N, Moeyersons J, Martens K, Gebreyohannes T, Deckers J, Walraevens K. 2010a. Impact of soil and water conservation measures on catchment hydrological response - a case in north Ethiopia. Hydrological Processes 24(13): 1880-1895.

Nyssen J, Govaerts B, Araya T, Cornelis WM, Bauer H, Haile M, Sayre K, Deckers J. 2010b. The use of the marasha ard plough for conservation agriculture in northern Ethiopia. Agronomy for Sustainable Development 31(2): 287-297

Nyssen J, Haile M, Poesen J, Deckers J, Moeyersons J. 2001. Removal of rock fragments and its effect on soil loss and crop yield, Tigray, Ethiopia. Soil Use and Management 17(3): 179-187. DOI:10.1111/ j.1475-2743.2001.tb00025.x.

Nyssen J, Poesen J, Gebremichael D, Vancampenhout K, D'aes M, Yihdego G, Govers G, Leirs H, Moeyersons J, Naudts J, Haregeweyn N, Haile M, Deckers J. 2007. Interdisciplinary onsite evaluation of stone bunds to control soil erosion on cropland in northern Ethiopia. Soil \& Tillage Research 94(1): 151-163. DOI:10.1016/j.still.2006.07.011.

Nyssen J, Poesen J, Haile M, Moeyersons J, Deckers J. 2000. Tillage erosion on slopes with soil conservation structures in the Ethiopian highlands. Soil and Tillage Research 57(3): 115-127. DOl:10.1016/ S0167-1987(00)00138-0.
Nyssen J, Poesen J, Moeyersons I, Deckers J, Haile M, Lang A. 2004. Human impact on the environment in the Ethiopian and Eritrean highlands - a state of the art. Earth-Science Reviews 64(3-4): 273-320. DOI:10.1016/S0012-8252(03)00078-3.

Nyssen J, Poesen J, Moeyersons J, Haile M, Deckers J. 2008. Dynamics of soil erosion rates and controlling factors in the northern Ethiopian Highlands - towards a sediment budget. Earth Surface Processes and Landforms 33(5): 695-711. DOI:10.1002/esp.156.

Nyssen J, Vandenreyken H, Poesen J, Moeyersons J, Deckers J, Mitiku H, Salles C, Govers G. 2005. Rainfall erosivity and variability in the northern Ethiopian Highlands. Journal of Hydrology 311(1-4): 172-187. DOl:10.1016/j.jhydrol.2004.12.016.

Poesen J, Nachtergaele J, Verstraeten G, Valentin C. 2003. Gully erosion and environmental change: importance and research needs. Catena 50(2-4): 91-133. DOI:10.1016/S0341-8162(02)00143-1.

Poesen J, Torri D, Bunte K. 1994. Effects of rock fragments on soil erosion by water at different spatial scales: a review. Catena 23(1-2): 141-166. DOI:10.1016/0341-8162(94)90058-2.

Poesen JW, van Wesemael B, Bunte K, Benet AS. 1998. Variation of rock fragment cover and size along semiarid hillslopes: a case-study from southeast Spain. Geomorphology 23: 323-335. DOI:10.1016/S0169555X(98)00013-0.

Poppe L, Frankl A, Poesen J, Admasu T, Dessie M, Adgo E, Deckers J, Nyssen J. 2013. Geomorphological map of the Lake Tana basin (Ethiopia). Journal of Maps 9(3): 431-437. DOI:10.1080/17445647.2013.801000.

Reij C. 1996. Indigenous Soil and Water Conservation in Africa. No. 27. Sustainable Agriculture Programme of the International Institute for Environment and Development: London.

Robinson M. 1990. Impact of Improved Land Drainage on River Flows, Report No. 113. Institute of Hydrology: Wallingford.

Rodriguez-Blanco ML, Taboada-Castro MM, Taboada-Castro MT. 2013. Linking the field to the stream: soil erosion and sediment yield in a rural catchment, NW Spain. Catena 102: 74-81. DOI:10.1016/j. catena.2010.09.003.

Schürz C, Schwen A, Strohmeier S, Klik A. 2013. Do Stone Bunds Affect Soil Physical Properties? A Case Study in Northern Ethiopia. Paper presented at the EGU General Assembly 2013, Vienna, Austria. Geophysical Research Abstracts, Vol. 15, EGU2013-4880-1.

Setegn SG, Srinivasan R, Melesse AM, Dargahi B. 2010. SWAT model application and prediction uncertainty analysis in the Lake Tana Basin, Ethiopia. Hydrological Processes 24(3): 357-367. DOI:10.1002/hyp.7457.

Shiferaw M. 2002. Linking Indigenous with 'Conventional' Measures for Substainable Land Management in the Highlands of Ethiopia: A Case Study of Digil Watershed, East Gojjam, Unpublished Thesis. College of Social Sciences, Addis Ababa University.

Simon A, Rinaldi M. 2006. Disturbance, stream incision, and channel evolution: the roles of excess transport capacity and boundary materials in controlling channel response. Geomorphology 79(3-4): 361-383. DOI:10.1016/j.geomorph.2006.06.037.

Skaggs RW, Brevé MA, Gilliam JW. 1994. Hydrologic and water quality impacts of agricultural drainage. Critical Reviews in Environmental Science and Technology 24(1): 1-32. DOI:10.1080/ 10643389409388459

Spaling H, Smit B. 1995. A conceptual model of cumulative environmental effects of agricultural land drainage. Agriculture, ECOsystems \& Environment 35(2): 99-108. DOI:10.1016/0167-8809 (94)00566-W.

Taye G, Poesen J, Wesemael BV, Vanmaercke M, Teka D, Deckers J, Goosse T, Maetens W, Nyssen J, Hallet V, Haregeweyn N. 2013. Effects of land use, slope gradient, and soil and water conservation structures on runoff and soil loss in semi-arid northern Ethiopia. Physical Geography 34(3): 236-259. DOI:10.1080/02723646.2013.832098.

Tardif S, St-Hilaire A, Roy R, Bernier M, Payette S. 2009. Statistical properties of hydrographs in minerotrophic fens and small lakes in mid-latitude Québec, Canada. Canadian Water Resources Journal 34(4): 365-380. DOI:10.4296/cwrj3404365.

Tebebu TY, Abiy AZ, Dahlke HE, Easton ZM, Zegeye AD, Tilahun SA, Collick AS, Kidnau S, Moges S, Dadgari F, Steenhuis TS. 2010. Surface and subsurface flow effect on permanent gully formation and upland erosion near Lake Tana in the Northern Highlands of Ethiopia. Hydrology and Earth System Sciences 14(11): 2207-2217. DOI:10.5194/hess-14-2207-2010. 
Thomasson AJ. 1975. Hydrological and environmental aspects. In Soils and Field Drainage. Technical Monograph No. 7, Thomasson AJ (ed). Soil Survey of England and Wales: Harpenden; 62-65.

Turkelboom F, Poesen J, Trebuil G. 2008. The multiple land degradation effects caused by land-use intensification in tropical steeplands: a catchment study from northern Thailand. Catena 75(1): 102-116. DOI:10.1016/j.catena.2008.04.012.

Vancampenhout K, Nyssen J, Gebremichael D, Deckers J, Poesen J, Haile M, Moeyersons J. 2006. Stone bunds for soil conservation in the northern Ethiopian Highlands: impacts on soil fertility and crop yield. Soil and Tillage Research 90(1): 1-15. DOI:10.1016/j. still.2005.08.004.

Wilkinson ME, Quinn PF, Benson I, Welton P. 2010. Runoff management: mitigation measures for disconnecting flow pathways in the Belford Burn catchment to reduce flood risk. Proceedings of the British Hydrological Society International Symposium 2010, Newcastle upon Tyne.
Wischmeier WH, Smith DD. 1978. Predicting Rainfall Erosion Losses: A Guide to Conservation Planning. Agriculture Handbook, Vol. 537. US Department of Agriculture: Washington, DC.

Woodward DE. 1999. Method to predict cropland ephemeral gully erosion. Catena 37(3): 393-399. DOI:10.1016/S0341-8162(99)00028-4.

Zegeye AD, Steenhuis TS, Blake RW, Kidnau S, Collick AS, Dadgari F. 2010. Assessment of soil erosion processes and farmer perception of land conservation in Debre Mewi watershed near Lake Tana, Ethiopia. Ecohydrology and Hydrobiology 10(2-4): 197-306. DOI:10.2478/v10104-011-0013-8.

Zhang ZY, Kong LL, Zhu L, Mwiya RM. 2013. Effect of drainage ditch layout on nitrogen loss by runoff from an agricultural watershed. Pedosphere 23(2): 256-264. DOI:10.1016/S1002-0160(13)60014-4.

Ziegler A, Sutherland RA, Giambelluca TW. 2000. Runoff generation and sediment production on unpaved roads, footpaths and agricultural land surfaces in northern Thailand. Earth Surface Processes and Landforms 25(5): 519-534. 